\title{
The Orange-breasted Falcon Falco deiroleucus in Mesoamerica: a vulnerable, disjunct population?
}

\author{
AARON J. BAKER, DAVID F. WHITACRE, OSCAR A. \\ AGUIRRE-BARRERA, and CLAYTON M. WHITE
}

\section{Summary}

The Orange-breasted Falcon Falco deiroleucus, among the world's most poorly known falcons, is sparsely distributed in Neotropical forests from south-east Mexico or Guatemala to Paraguay and northern Argentina. Details of distribution and population size are poorly known throughout the species's range. From 1992 to 1997 we studied this species at 19 nest sites in Guatemala and Belize. Occupancy and productivity rates remained stable for this northernmost population over this six-year period. Sparse data on historical distribution preclude a full assessment of possible changes in population status in the Mesoamerican portion of the species's range. Today the species appears restricted to forested areas in conjunction with large nesting cliffs. No breeding record is known for any Mesoamerican nation except Belize and Guatemala. Mean number of fledglings per successful nesting was significantly higher in areas of predominantly forested mosaic habitat $(2.11, n=18)$ than at sites with uninterrupted mature forest $(1.36$, $n=11$ ); proportion of sites occupied and of pairs fledging young did not differ between these two habitats. Based on historical and current distribution records and distribution of potential nesting habitat, we conclude that the Guatemala/Belize population of Orange-breasted Falcons is disjunct from the species's main range in South America, is perhaps the only local population (at best one of a small number) in Mesoamerica, and is tightly linked to the existence of suitable nesting cliffs combined with large forested areas.

\section{Introduction}

The Orange-breasted Falcon Falco deiroleucus occurs in New World tropical forests from Guatemala, Belize, and possibly southeast Mexico, south to northern Argentina, Paraguay and Bolivia (Brown and Amadon 1968, del Hoyo et al. 1994). Nesting on large cliffs or emergent trees, typically in areas of lowland or lower montane primary forest, this species is among the least known and perhaps one of the most sparsely distributed falcons in the world. Although in Ecuador Orange-breasted Falcons were found nesting in large, emergent trees (Jenny and Cade 1986), in Mesoamerica (Mexico plus Central America) this species appears to nest almost exclusively on cliffs, with only one instance of tree nesting known (J. Baker, D. Whitacre, O. Aguirre-Barrera and C. White unpubl.). These mediumsized falcons hunt above the forest canopy for birds and bats, and are among the very few Falco species that occur primarily in tropical forest (Cade 1982).

The presence of the Orange-breasted Falcon as a breeding species in northern 
Central America has been known since 1959 (Smithe and Paynter 1963), but to our knowledge, only the pair nesting periodically on the Maya temples of Tikal National Park in Guatemala and one at a waterfall in Belize, are widely known. In 1979, Jenny and Cade (1986) searched for additional pairs of this species in Petén, Guatemala and in Belize, locating four nest sites in Guatemala and none in Belize. Elsewhere in Mesoamerica, the distribution and status of this species has remained largely unknown.

Ramos (1986) speculated that these falcons were extinct in Mexico, and the species is listed as endangered by the Costa Rican government (Stiles 1985). Globally, the species was regarded as near-threatened by Collar et al. (1992), with which we concur. Several authors have suggested that these falcons favour ecotones or habitat mosaics of disturbed and undisturbed forests (Slud 1964, Haverschmidt 1968, Howell 1972, Boyce 1980), while others have proposed that this species relies largely on primary forest and is sensitive to habitat alteration (Thiollay 1985, Ellis and Smith 1986, Jenny and Cade 1986).

From 1992 to 1997 we studied the ecology, behaviour and population status of this species at 19 nest sites in Guatemala and Belize. Our initial task was to explore the size of this scarcely documented, northernmost known population, and to find enough nesting pairs to study. Beyond this, the focus of our research was on documenting aspects of life history and behaviour, and monitoring nest site occupancy and productivity rates. In addition, we have attempted to evaluate the conservation status of the species throughout Mexico and Central America. In this effort, we have proceeded as far as possible based on our data on habitat affinity, nest site requirements, trends in demographic parameters of the study population, and review of existing distributional information. Beyond this it has been necessary to make inferences about the possible distribution and magnitude of populations based on distribution of potential nesting habitat.

Our objectives in this paper are threefold: (1) to clarify the species's historical and current distribution in Mesoamerica; (2) analyse six years of occupancy and reproductive data for possible trends; and (3) discuss the species's future welfare in the northern portion of its range and conservation actions that might help secure it.

\section{Study area}

This research was conducted in the Petén Department of Guatemala and throughout Belize. Elevation in Petén ranges from 100 to $600 \mathrm{~m}$; topography is gently rolling, broken in a few areas by steep, jumbled karst terrain and, rarely, by large escarpments featuring cliffs. Belize is similar, but includes the Maya Mountains, a range including extensive karst, that reaches $1,120 \mathrm{~m}$, and is transected by several major river systems, in places forming tall cliffs. This cliff-laden range remains largely forested in Belize, but has lost much forest cover where it extends into Guatemala. Climate is lowland tropical with mean annual temperature of $26.6{ }^{\circ} \mathrm{C}$ and annual rainfall between 150 and $200 \mathrm{~cm}$ (Secretaria de Programación y Presupuesto 1981). A pronounced dry season is typical, from about February to May or mid-June, with highest rainfall in September. Vegetation in northern Petén is semi-deciduous tropical forest that varies along a subtle topographic continuum (Lundell 1937, Pennington and Sarukhan 1968). In welldrained areas the canopy is closed, $25-30 \mathrm{~m}$ tall, with an open understorey and 
diverse tree species, whereas in low-lying sites the canopy is more open, $10-15$ $\mathrm{m}$ tall, different in tree species composition, and has a denser understorey (Schulze and Whitacre 1999). Vegetation in Belize is similar, though rainfall is higher in some areas, leading to differences in the semi-deciduous tropical forest cover. At higher elevations in the Maya Mountains, Caribbean pine Pinus caribaea forests dominate the landscape, interspersed with broadleaf riparian vegetation.

\section{Methods}

\section{Population monitoring and analysis of demographic data}

In 1991 we began collecting data on productivity and occupancy of the six nesting sites known at the time, and in 1992 began searching in earnest for additional pairs in Guatemala and Belize. To date we have located six nest sites in Guatemala and 13 in Belize. Each year from 1992 to 1997 we visited most previously documented nest sites and searched for additional pairs. To locate new nest sites, we questioned local people, examined topographic maps for areas with cliffs, explored river valleys by boat and on foot, drove roads through areas of high relief, and searched for cliffs from fixed-wing aircraft. When cliffs or verticalwalled sinkholes were located, we visited them and spent several hours observing in an effort to determine whether falcons occupied them. To verify occupancy and measure productivity, we visited nest sites once or twice each year, typically early in the season during courtship or incubation (February-March), and again late in the season just after young typically fledged (June-July). Four of the 19 nest sites were omitted from most analyses; two of the four were monitored only one year due to difficulty of access and two were occupied for only one year.

For analyses of occupancy and nesting success in relation to habitat modification, nest sites were grouped into two categories: mature forest and habitat mosaic. Mature forest nest sites $(n=7)$ were those surrounded by mature forest for at least a $5 \mathrm{~km}$ radius. Habitat mosaic nest sites $(n=8)$ were those that had some deforestation or forest modification $(<50 \%$ of the area within a $5 \mathrm{~km}$ radius of the nest site) in the form of successional forest, agriculture or pasture. Data for all years were combined to assess differences in reproduction and occupancy between the two habitat categories.

To test for trends over time in the annual proportion of nest sites occupied and in the proportion of pairs producing one or more young, we used binary logistic regression. We used ordinal logistic regression to test for trends in annual mean number of young fledged by successful pairs. In the analysis of annual percentage of sites occupied, we omitted the year in which a site was discovered, and hence must have been occupied. We tested for differences in productivity and occupancy between undisturbed and modified habitats using multiple random permutation procedure (MRPP) $\chi^{2}$ tests (Berry and Mielke 1986) and $t$-tests. Logistic regression and $t$-tests were conducted using MINITAB 11 (1996).

\section{Results}

\section{Nest site characteristics}

In Guatemala and Belize, 18 of 19 nest sites we located were on cliffs and one was on the leaf spathe of an emergent palm Orbignya cohune, the first known 
record of tree-nesting in Central America. Nesting cliffs averaged $125 \pm 89 \mathrm{~m}$ (SD) in height (range $=35-400 \mathrm{~m}, n=18)$ and $243 \pm 145 \mathrm{~m}$ in width (range $=15-$ $600 \mathrm{~m}, n=16$ ). Eyrie sites on cliffs ranged from exposed ledges to deep potholes, typically near the centre of the cliff. All sites were in mature forest $(n=11)$ or habitat mosaics dominated by mature forest $(n=7)$. Fifteen nest sites were in river valleys or on escarpments in the immediate vicinity of water, usually a small creek or river. While at times pairs nested as close together as $1.7 \mathrm{~km}$, on average they were $7.6 \pm 6.1 \mathrm{~km}$ apart within local population nuclei (range $=1.7-$ $19.2 \mathrm{~km}, n=17$, omitting two outliers with nearest-neighbour distances of 74 and $54 \mathrm{~km}$ ). Considered on a broader regional scale, densities were much lower than implied by these local nearest-neighbour distances.

\section{Historical and current distribution}

Table 1 summarizes nesting, specimen and sight records known to us for this species in Central America and Mexico. With the exception of Guatemala and Belize, all records that we consider reliable are more than 20 years old. The extreme similarity of the Orange-breasted Falcon to the much commoner Bat Falcon F. rufigularis routinely leads to confusion of these two species in the field (Howell and Whittaker 1995), and several of the sight records in Table 1 are questionable for this reason. Griscom's (1932) account of nesting in "cathedral and church towers and belfries in the heart of towns and cities" is likely based on confusion with the Bat Falcon, as has been pointed out by several authors (Wetmore 1965, Howell 1972). Likewise, a recent published sight record from Costa Rica (Herman and Hedstron 1991) is open to doubt.

The only nesting records known from Mesoamerica are from Guatemala and Belize (Table 1). In Mexico, a single, old specimen record from Veracruz (Friedmann 1950) is the best evidence of the species's historical presence, followed by one published sighting with adequate descriptive detail (Hardy et al. 1975). All other sightings in Mexico (Table 1) are of unknown reliability and none is recent. For Honduras, the only conclusive evidence of the species's presence is a single 1937 specimen (Monroe 1968), although a falcon shot and eaten during the mid-1990s by local hunters near Agalta in the Department of Olancho may have been of this species (S. Midence, pers. comm.); this is an area with large cliffs and extensive forest. The only Nicaraguan specimen was collected in 1962, $40 \mathrm{~km}$ from the Honduran border and near a cliff-laden mountain range on the Honduran side (Howell 1972). We know of no historical records for El Salvador, and little forest now remains there (Thurber et al. 1987). The few specimen records for Costa Rica and Panama date from the nineteenth century, and Stiles and Skutch (1989) stated that no definite record was known for Costa Rica in the previous 30 years. Likewise, Ridgely and Gwynne (1989) stated that for Panama no definite evidence exists for this century, with possible sightings in 1957 and 1970. Based on these data, we conclude that Orange-breasted Falcon distribution in Central America is extremely localized and largely limited to areas with suitable cliffs in predominantly forested areas.

\section{Nest productivity, occupancy and habitat}

Table 2 summarizes our annual occupancy and productivity data and the results of logistic regression analyses. We found no significant trends over time in the 
Table 1. Summary of Orange-breasted Falcon nesting, specimen, and sight records for Mexico and Central America

\begin{tabular}{|c|c|c|c|}
\hline Country & Nesting records & Specimen records & Sight records \\
\hline Mexico & None & $\begin{array}{l}\text { Friedmann } 1950 \\
\text { (Veracruz) }\end{array}$ & $\begin{array}{l}\text { M. Alvarez del Toro } \\
\text { 1955, 1973 (both } \\
\text { Chiapas) }^{\mathrm{a}} \\
\text { W. Schaldach } 1972 \\
\text { (Veracruz) }^{\mathrm{b}} \\
\text { Hardy et al. (1976) } \\
\text { (Campeche) }_{\text {J. Hardy 1977 }} \\
\text { (Veracruz) }^{\mathrm{a}} \\
\text { L. Wolfe } 1977 \text { (Tabasco) }^{\mathrm{a}}\end{array}$ \\
\hline Belize & $\begin{array}{l}\text { Whitacre and Jenny } \\
\text { (1991), Baker et al. (1992), } \\
\text { this study }\end{array}$ & None & $\begin{array}{l}\text { Haney (1983), many } \\
\text { others at one } \\
\text { well-known eyrie site }\end{array}$ \\
\hline Guatemala & $\begin{array}{l}\text { Smithe and Paynter } \\
\text { (1963), Smithe (1966), } \\
\text { Boyce (1980), Jenny and } \\
\text { Cade (1986), Whitacre and } \\
\text { Jenny (1991), Baker et al. } \\
\text { (1992), this study }\end{array}$ & $\begin{array}{l}\mathrm{AMNH}^{\mathrm{c}} \text { No. } 393655, \\
\text { collected in } 1931\end{array}$ & $\begin{array}{l}\text { Our own sightings } \\
\text { associated with known } \\
\text { eyries }\end{array}$ \\
\hline Honduras & None & Monroe (1968) & S. Midence $1997^{a}$ \\
\hline El Salvador & None & None & None \\
\hline Nicaragua & None & $\begin{array}{l}\text { 1962, reported in Howell } \\
(1972)\end{array}$ & Griscom $(1932)^{\mathrm{d}}$ \\
\hline Costa Rica & None & $\begin{array}{l}\text { USNM }^{\mathrm{e}} \text { No. } 51293, \\
\text { collected in } 1867, \mathrm{AMNH}^{\mathrm{c}} \\
\text { No. } 45 \mathrm{O} 24, \text { no date but old }\end{array}$ & $\begin{array}{l}\text { Slud (1964) } \\
\text { Herman and Hedstron } \\
(1991)^{d}\end{array}$ \\
\hline Panama & None & $\begin{array}{l}\text { an } 1869 \text { specimen and } \\
\text { another, mentioned by } \\
\text { Wetmore (1965) }\end{array}$ & $\begin{array}{l}\text { Griscom }(1932)^{\mathrm{d}} \\
1957(\text { Wetmore 1965) }\end{array}$ \\
\hline
\end{tabular}

a Personal communication, written correspondence.

${ }^{\mathrm{b}}$ Unpublished manuscript.

c American Museum of Natural History.

d See text for discussion of record validity.

e United States National Museum.

annual percentage of sites occupied, percentage of pairs fledging one or more young, or the number of young fledged at successful sites; this was true using data from all sites and restricting analyses to those $(n=9)$ sites monitored yearly from 1993 to 1997. The mean number of fledglings per successful nesting was significantly higher in areas of mosaic habitat than at mature forest sites (Table 3). No significant differences were found between mature forest and mosaic sites in the proportion of sites occupied or of pairs fledging one or more young.

\section{Discussion}

\section{Demographic trends}

Falcons in our sample from Guatemala and Belize appeared to be maintaining steady reproductive and nest site occupancy rates, suggesting a stable local population. However, it is unknown whether these results can be validly extra- 


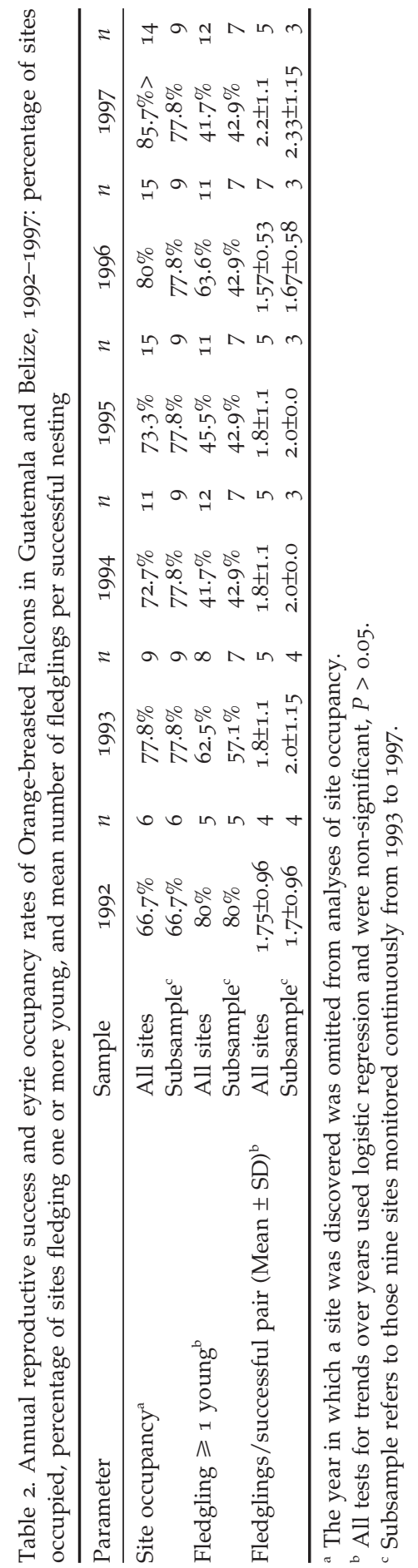


Table 3. Orange-breasted Falcon site occupancy and reproductive performance at mature forest and habitat mosaic sites, 1992-1997

\begin{tabular}{lccc}
\hline Parameter & Mature forest sites & Habitat mosaic sites & $P$ \\
\hline Site occupancy & $73.3 \%(n=35)$ & $77.8 \%(n=36)$ & $0.727^{\mathrm{a}}$ \\
Pairs fledging $\geqslant 1$ young & $40.7 \%(n=27)$ & $62.5 \%(n=32)$ & $0.098^{\mathrm{b}}$ \\
Fledglings/successful pair (Mean \pm SD) & $1.36 \pm 0.67(n=11)$ & $2.11 \pm 0.68(n=18)$ & $0.004^{\mathrm{c}}$ \\
\hline
\end{tabular}

${ }^{\mathrm{a}} \operatorname{MRPP} \chi^{2}=0.12$.

${ }^{\mathrm{b}} \operatorname{MRPP} \chi^{2}=2.73$.

${ }^{\mathrm{c}} t_{27}=2.89$.

polated to the regional population as a whole, nor is the size of the regional population known.

\section{Habitat relations}

The significantly higher mean number of fledged young in sites surrounded partly by altered habitats may lend support to several authors' suspicion that these falcons prefer ecotones, especially where mature forests border other habitat types. However, it is important to note that the habitat mosaic sites we studied were dominated by mature forest. Hence, the higher productivity we documented for sites in partly altered habitat does not imply that more heavily modified landscapes are also favourable to this species, and indeed, the eight pairs found by Jenny and Cade (1986) in Ecuador and Guatemala nested exclusively amid large expanses of mature forest. This species may not be absolutely reliant on pristine tropical forest habitat, but the fact that no nesting pairs have been found in predominantly deforested areas leads us to conclude that these falcons have an affinity for unmodified to slightly modified tropical forest habitat, at least in the Mesoamerican portions of their range.

\section{Nest site limitation}

In eastern Ecuador, J. P. Jenny (unpubl.) found a pair of Orange-breasted Falcons nesting in a platform-like crotch high in a huge ceiba Ceiba pentandra, and three other pairs, some with fledged young, defended similar large trees. In the same area, D. Pearson (pers. comm. to J. P. Jenny) previously documented nesting in a large ceiba. Jenny concluded that nesting in the spacious crotches of large emergent trees was frequent in Amazonian Ecuador (Jenny and Cade 1986). No doubt tree nesting occurs elsewhere and it would be worth publishing any observed instances; recent observations of this species deep in the Amazon Basin, where cliffs are rare (Whittaker 1996), may suggest that tree nesting is common there. However, all other instances of nesting known to us for South America involve cliff nesting, which is known for Ecuador (F. Ortíz pers. comm. to J. P. Jenny), Peru, and Bolivia (J. O'Neill pers. comm. to J. P. Jenny). Thiollay (1989) stated that in French Guiana this falcon has never been found breeding other than on cliffs.

All evidence indicates that these falcons are predominately cliff nesters in Mesoamerica. We base this conclusion partly on our experience studying forest 
raptors in northern Petén, Guatemala. From 1988 to 1996, we studied 20 species of forest raptors in and near Tikal National Park in northern Petén, fielding up to 50 persons for six months of field work each year (Whitacre 1998). During these many person-years spent in the forest studying raptors, we found only one instance of tree nesting by Orange-breasted Falcons.

For cliff-nesting populations of Peregrine Falcons Falco peregrinus it is well accepted that nesting opportunities are generally limited by availability of suitable nesting cliffs in conjunction with food supply, with territorial behaviour further limiting nesting density when suitable cliffs are close enough together to provoke intolerable interactions among neighbours (Ratcliffe 1962, Hunt 1988). We envision a similar mode of nest site limitation in Orange-breasted Falcons in Mesoamerica.

\section{Potential nesting habitat}

Although the presence of this species in Mesoamerica beyond Belize and Guatemala is poorly documented, other areas where moist, lowland or lower montane forest occurs in conjunction with large cliffs are potential nesting habitat. Remote, forested regions of south-east Mexico harbour world-renowned karst regions, with significant cliffs and vertical-walled pit-caves that may serve as nest sites; in spite of the lack of nesting records, it seems likely that a small breeding population is or was resident in this area. Honduras has several areas of rugged, extensively forested karst terrain, where the massively bedded Atima Limestone forms numerous cliffs in some areas (R. Finch, J. Fogarty and S. Wotkins pers. comm.). Hence it is to be expected that Honduras houses a largely undocumented population of this species. Limestone outcrops and karst geology are less common in Nicaragua than in Honduras, and there is less vertical relief, so fewer cliffs are expected (R. Finch pers. comm.). However, some mountainous karst occurs near the Honduran border, and may provide limited nesting habitat ( $R$. Finch and B. Dickson pers. comm.). Costa Rica is largely without limestone cliffs; most "cliffs" there are volcanic, less than vertical, and largely draped with forest (pers. obs.), and probably unfavourable for nesting by this species. We have no knowledge of the prevalence of cliffs in Panama.

\section{Conservation}

Typically, field guides and other general accounts refer to this species as rare and localized in occurrence. For Mesoamerica, we would refine this description as follows: this species is rare and localized, with local populations centred in areas where abundant large cliffs occur amidst extensive forest. Most nest cliffs observed to date have been limestone cliffs with numerous potholes, some of which serve as nest sites. Hence, the species's rarity and localized distribution appears to be due at least in part to the limited extent of forested karst regions with abundant limestone cliffs.

We suspect that the present existence and future welfare of the Guatemala/ Belize enclave of Orange-breasted Falcons is linked to the vast areas of lowland forest remaining here in conjunction with cliff-forming geological strata. Together with adjacent forests in Mexico, these comprise the largest tracts of 
lowland tropical forest remaining north of Panama. Though much of this landscape is nominally protected, forest here continues to be altered by a rapidly increasing human population and attendant slash-and-burn farming, conversion to citrus orchards, cattle ranching and logging (Sader et al. 1994, 1997, Whitacre 1997).

In the interest of conserving this northernmost known aggregation of Orangebreasted Falcons, we feel it is wise to assume that this local population is essentially disjunct from the presumed main portion of the species's population in South America, with infrequent gene flow and a rate of immigration that is negligible from the standpoint of any potential natural rescue effect. Although one or more population foci may exist further south in Central America, these too (if indeed they exist) are likely to be small and probably experience little immigration from the species's South American populations.

The fact that Orange-breasted Falcons remain as resident breeders in Petén and Belize despite the undoubtedly small size and probable isolation of this enclave may indicate that this population possesses some resiliency to adverse factors known to affect small populations. However, we suspect that this northernmost population is inherently vulnerable due to its small size, and that every historic nest site is important to population maintenance. We suggest that the most serious threat to this enclave of falcons is the continuing tide of habitat conversion. Our observations in many portions of Mesoamerica indicate that, though steep karst landscapes are often deforested more slowly than are areas of more moderate relief, even such rugged areas often suffer extreme deforestation in the end (pers. obs.). Accordingly, our main management recommendation is that attention be given to conservation of large forest tracts in areas of abundant cliffs. As such cliff-bearing areas are often in karst landscapes, their protection can also benefit other karst-associated species such as endemic cave-dwelling organisms.

In addition, we urge further efforts to document the distribution and abundance of this falcon throughout Latin America. While we presume the bulk of the species's global population resides south of Panama, this falcon's distribution and abundance in South America remain poorly known, and nowhere has its population density yet been found to rival that demonstrated in Belize. Whether the South American population in aggregate is large, and whether (and where) local populations may rival or exceed the density of that we discovered in Belize and Petén remain unknown.

\section{Acknowledgements}

This is a contribution of the "Maya Project", a conservation research effort of The Peregrine Fund. We gratefully acknowledge Robert Berry for financial support for this research, and W. Burnham, J. P. Jenny and T. J. Cade for advice throughout the study. Fieldwork was assisted by William Morales, Sherry Hudson, Nat Seavy, Lenny Gentle, Erin B. Girdler, Benjamín Gonzalez Córdova, Juventino López Avila and Mark Schulze. Flight surveys of Belize were made possible with help from Lighthawk. Gary Falxa and Dean Hector provided records of personal communications and correspondence from J. Hardy and L. Wolfe. We are grateful to Steve Herman, Hal Black, Mark Belk, 
Lloyd Kiff, Tom Cade, Jim Enderson and Steve Beissinger for helpful comments on earlier drafts of the manuscript. Research in Guatemala and Belize was conducted under permit of the Consejo Nacional de Areas Protegidas and Belize Forestry Department respectively.

\section{References}

Baker, A. J., Jenny, J. P. and Whitacre, D. F. (1992) Orange-breasted Falcon reproduction, density, and behavior in Guatemala and Belize. Pp. 217-224 in D. F. Whitacre and R. K. Thorstrom, eds. Progress Report V, 1992, Maya Project. Use of raptors and other fauna as environmental indicators for design, management, and monitoring of protected areas and for building local capacity for conservation in Latin America. Boise, ID: The Peregrine Fund.

Berry, K. J. and Mielke, P. W. Jr. (1986) R by C chi-square analyses with small expected cell frequencies. Educ. Psychol. Measure. 46:169-173.

Boyce, D. A., Jr. (1980) Hunting and prenesting behavior of the Orange-breasted Falcon. J. Raptor Res. 14: 35-39.

Brown, L. and Amadon, D. (1968) Eagles, hawks and falcons of the world. New York: McGraw-Hill.

Cade, T. J. (1982) The falcons of the world. Ithaca, NY: Comstock/Cornell University Press. Collar, N. J., Gonzaga, L. P., Krabbe, N., Madroño Nieto, A., Naranjo, L. G., Parker III, T. A. and Wege, D. C. (1992) Threatened birds of the Americas: the ICBP/IUCN red data book. Third edition, part 2. Washington, D.C.: Smithsonian Institution Press.

del Hoyo, J., Elliott, A., and Sargatal, J. (eds) (1994) Handbook of the birds of the world. 2. New World vultures to guineafowl. Barcelona: Lynx edicions.

Ellis, D. H. and Smith, D. G. (1986) An overview of raptor conservation in Latin America. Birds of Prey Bull. 3: 21-25.

Friedmann, H. (1950) Birds of North and Middle America. Bull. U.S. Nat. Mus. 180: 171674 .

Griscom, L. (1932) The distribution of bird life in Guatemala. Bull. Amer. Mus. Nat. Hist. Vol. LXIV.

Haney, C. (1983) First sight record of Orange-breasted Falcon for Belize. Wilson Bull. 95: 314-315.

Hardy, J. W., Raitt, R. J., Orejuela, J., Webber, T. and Edinger, B. (1975) First observation of the Orange-breasted Falcon in the Yucatan Peninsula of Mexico. Condor 77: 512.

Haverschmidt, F. (1968) Birds of Surinam. Edinburgh: Oliver and Boyd.

Herman, T. B. and Hedstron, I. (1991) The Orange-breasted Falcon (Falco deiroleucus) in Costa Rica gone for thirty years? Brenesia 34: 153-154.

Howell, S. N. G. and Whittaker, A. (1995) Field identification of Orange-breasted and Bat Falcons. Cotinga 4: 36-43.

Howell, T. R. (1972) Birds of the lowland Pine savanna of northeastern Nicaragua. Condor 74: 316-340.

Hunt, W. G. (1988) The natural regulation of Peregrine Falcon populations. Pp. 667-676 in T. J. Cade, J. H. Enderson, C. G. Thelander and C. M. White, eds. Peregrine Falcon populations: their management and recovery. Boise, ID: The Peregrine Fund.

Jenny, J. P. and Cade, T. J. (1986) Observations of the biology of the Orange-breasted Falcon (Falco deiroleucus). Birds of Prey Bull. 3: 119-124.

Lundell, C. L. (1937) The vegetation of Petén. Washington, D.C.: Carnegie Institute (Publ. 478).

Monroe, B. L. (1968) A distributional survey of the birds of Honduras. Washington, D.C.: American Ornithologists' Union (Orn. Monogr. 7). 
MINITAB (1996) MINITAB user's guide. Release 11 for Windows. State College, Pennsylvania: MINITAB, Inc.

Pennington, T. D. and Sarukhan, J. (1968) Arboles tropicales de Mexico. Mexico, Distrito Federal: Instituto Nacional de Investigaciones Forestales.

Ramos, M. A. (1986) Birds in peril in Mexico: the diurnal raptors. Birds of Prey Bull. 3: 26-47.

Ratcliffe, D. (1962) Breeding density in the Peregrine Falco peregrinus and Raven Corvus corax. Ibis 104: 13-39.

Ridgely, R. S. and Gwynne, J. A. Jr. (1989) A guide to the birds of Panama: with Costa Rica, Nicaragua, and Honduras. Princeton: Princeton University Press.

Sader, S. A., Sever, T., Smoot, J. C. and Richards, M. (1994) Forest change estimates for the northern Petén region of Guatemala, 1986-1990. Hum. Ecol. 22: 317-332.

Sader, S. A., Reining, C., Sever, T. and Soza, C. (1997) Human migration and agricultural expansion: a threat to the Maya tropical forests. J. Forestry 1997: 27-32.

Schulze, M. D. and Whitacre, D. F. (1999) A classification and ordination of the tree community of Tikal National Park, Petén, Guatemala. Bull. Florida Mus. Nat. Hist. 41: 169297.

Secretaria de Programacion y Presupuesto. (1981) Carta de climas 1:1,000,000, Merida. Mexico, Distrito Federal: Direccion General de Geografía del Territorio Nacional.

Slud, P. (1964) The birds of Costa Rica. Bull. Amer. Mus. Nat. Hist. 128: 73.

Smithe, F. B. (1966) The birds of Tikal. Garden City, NY: The Natural History Press.

Smithe, F. B. and Paynter, R. A., Jr. (1963) Birds of Tikal, Guatemala. Bull. Mus. Comp. Zool. 128: 245-324.

Stiles, F. G. (1985) Conservation of forest birds in Costa Rica: problems and perspectives. Pp. 141-168 in A. W. Diamond and T. E. Lovejoy, eds. Conservation of tropical forest birds. Cambridge, U.K.: International Council for Bird Preservation (Techn. Publ. 4).

Stiles, F. G. and Skutch, A. F. (1989) A guide to the birds of Costa Rica. Ithaca, NY: Comstock/Cornell Univ. Press.

Thiollay, J. M. (1985) Composition of falconiform communities along successional gradients from primary rainforest to secondary habitats. Pp. 181-190 in I. Newton and R. D. Chancellor, eds. Conservation studies on raptors. Cambridge, U.K.: International Council for Bird Preservation (Techn. Publ. 5).

Thiollay, J. M. (1989) Area requirements of rain forest raptors and game birds in French Guiana. Conserv. Biol. 3: 128-137.

Thurber, W. A., Serrano, J. F., Sermeño, A. and Benitez, M. (1987) Status of uncommon and previously unreported birds of El Salvador. Proc. West. Found. Vert. Zool. 3: 109293.

Wetmore, A. (1965) The birds of the Republic of Panama. 1. Tinamidae (Tinamous) to Rynchopidae (Skimmers). Smithson. Misc. Coll. 50.

Whitacre, D. F. (1997) El estado de la Reserva de la Biósfera Maya en 1996. Boise, ID: The Peregrine Fund.

Whitacre, D. F. (1998) The Peregrine Fund's Maya Project: ecological research, habitat conservation efforts, and development of human resources in the Maya Forest. Pp. 241266 in R. B. Primack, D. Bray, H. A. Galletti and I. Ponciano, eds. Timber, tourists, and temples: conservation and development in the Maya Forest of Belize, Guatemala, and Mexico. Washington, DC: Island Press.

Whitacre, D. F. and Jenny, J. P. (1991) Orange-breasted Falcon survey work in Guatemala and Belize. Pp. 137-143 in D. F. Whitacre, W. A. Burnham and J. P. Jenny, eds. Progress Report IV, 1991, Maya Project. Use of raptors and other fauna as environmental indicators for design and management of protected areas and for building local capacity for conservation in Latin America. Boise, ID: The Peregrine Fund. 
Whittaker, A. (1996) First records of the Orange-breasted Falcon Falco deiroleucus in central Amazonian Brazil, with short behavioural notes. Cotinga 6: 65-69.

AARON J. BAKER and DAVID F. WHITACRE ${ }^{1}$

The Peregrine Fund, 566 West Flying Hawk Lane, Boise, ID 83709, U.S.A.

OSCAR A. AGUIRRE-BARRERA

Fondo Peregrino, Parque Nacional Tikal, Flores, Petén, Guatemala

CLAYTON M. WHITE

Department of Zoology, Brigham Young University, Provo, UT 84602, U.S.A.

${ }^{1}$ Author for correspondence; e-mail: dwhitacre@peregrinefund.org 